\title{
A Freudian Psychoanalysis of Symbols in Faulkner's The Hamlet
}

\author{
Cao Mengyue ${ }^{1}$ \\ ${ }^{1}$ Department of Foreign Language, Yangtze University College of Arts and Sciences, Jingzhou, Hubei, China. \\ Correspondence: Cao Mengyue, Department of Foreign Language, Yangtze University College of Arts and Sciences, \\ Jingzhou, 434020, Hubei, China.
}

Received: July 21, 2016

Accepted: August 9, 2016

Available online: August 15, 2016

doi:10.11114/ijsss.v4i9.1808

URL: http://dx.doi.org/10.11114/ijsss.v4i9.1808

\begin{abstract}
William Faulkner is regarded as the representative of American Southern culture and literature. His works are famous for his writing techniques, artistic value and cultural setting. The Hamlet is one of Faulkner's great works set in the Southern America, and the novel is filled with symbols. According to Freud, symbols are often used as the agency to combine the conscious and the unconscious together. From the perspective of Freudian psychoanalysis, many symbolic images are related to the unconscious desire. Therefore, to understand a literary work well, it's better to ruin the surface structure of arts to seek the unconscious meanings from symbols like incidents, plots, details and sceneries in the work. There are three main symbols that symbolize people's unconscious desire in The Hamlet: the Eula's buggies, the village's activities and people's purchasing behavior. All these symbolize the original unconscious desire of the villagers in the Frenchman place. The psychoanalysis of these symbols in The Hamlet is beneficial to deepen our understanding of human nature embodied in the novel.
\end{abstract}

Keywords: The Hamlet, symbol, buggy, activity, purchase

\section{Introduction}

William Faulkner is a prolific Southern writer in modern America with nineteen long novels and a plenty of short stories. The majority of Faulkner's works take his hometown as the setting archetype to tell the stories and shape the characters. The archetype setting is known as Yoknapatawpha County in his works. The Sound and the Fury(1930), As I Lay Dying (1930), Sanctuary (1931), Light in August (1932), Absalom, Absalom (1936), Go Down, Moses (1942)and the Snopes trilogy: The Hamlet (1940), The Town (1957) and The Mansion (1959) are representatives of his Yoknapatawpha novels.

The Hamlet, the first volume of the Snopes trilogy, is one of Faulkner's representative works in his later life. It tells a story about Flem Snopes in the Frenchman's Bend. By playing tricks, Flem, an outsider of the village, gradually controls the business of the village, including the Varner's store, the Blacksmith shop and the flower house. In addition, he calls up his family members to the Frenchman's Bend to help him gain great profit. After selling the old house of the Old Frenchman place by deceiving Ratliff, Flem leaves the village and moves to Jefferson with the fortune. The Hamlet is a big exploration of Faulkner's creation, because it involves more society, politics and economics than his other works, and plays a critical role in William Faulkner's writing career by expanding his writing span in some sense. In the novel, Faulkner describes the atmosphere of society, economics and politics and the local folk customs in detail.

The Hamlet is considered the best volume with highest value among the trilogy. Once Faulkner said in one letter about The Hamlet: "I swear to the God that I am the best writer in America" (Xiao, 1997, P. 47), which not only demonstrates Faulkner's confidence in his own achievement in literature and his talent in art, but also shows the value of The Hamlet. One of its artistic values lies in the good use of symbols. Some of symbols are filled with religious connotation, some are related to sexual desire, and even some are combined to the desires for wealth and social position.

Sigmund Freud (1856-1939) is regarded as the pioneer of the psychoanalytic school. In 1898, he coined the word "psychoanalysis" and began to use the word to refer to a systematic structure of theories concerning the relation of conscious psychological processes, so we call psychoanalysis Freudian psychoanalysis. Freud believes that "any arts are objectified, systematized and visualized day-dreams, symbolizing the writer's unconscious desires" (Liao, 2008, P. 35). Therefore, it could be inferred that the consciousness and the unconsciousness are combined with each other by taking symbols as the agency in the solid structure of arts. The paper is to analyze unconscious desires behind the symbols in 
Faulkner's The Hamlet from the perspective of psychoanalysis.

\section{The Psychoanalysis of Symbols in The Hamlet}

Freudian psychoanalysis has a complicated system, but it mainly includes the theory of consciousness and unconsciousness, the theory of structure of personality, the conception of psychological drive, the theory of dream, the Oedipus complex and so on. Freud presents the following major points in these theories: The activities of human mind consist of the unconscious, the preconscious and the conscious; the unconsciousness is the initial drive of human's actions; the structure of human personality contains the id, the ego and the superego; human's instinct includes life instinct and death instinct; libido is the motivational source of erotic instinct; dream symbolizes the repressed instinctive desires, and dream is often produced by way of compressing, transplanting and reflecting; and any arts are objectified, systematized and visualized day-dreams, symbolizing the writer's unconscious desires and so forth.

Freud's psychoanalytic theories have made it possible to interpret human behaviors from a different perspective. The part is concerned with how Freud's psychoanalytic theories extend to explore the implied significance of symbols which are used in Faulkner's novel The Hamlet. In Freud's eyes, any literatures are systematized, visualized and symbolic day-dreams. To analyze a literary work, we should seek the unconscious meanings from symbols like incidents, plots, details and sceneries in the work.

A symbol is anything that is used to represent something other than itself. In another word, it means that A stands for B. In literature, symbolism is often used to add a broader, more abstract meaning to the story. According to Freud, arts are systematized, objectified and visualized day-dreams, symbolizing the writer's unconscious desires. In arts, symbols are often used as the agency to combine the outer and the inner, the consciousness and the unconsciousness together. Therefore, in order to have a thorough understanding of a literary work, it is advisable to break its surface structure to figure out the unconscious meanings from symbols in the work.

The use of symbols is quite outstanding in the Faulkner's works. His symbolic images are not obtained by chance, but conceived to strengthen the theme and help to shape characters. When we explore the deep meanings of these symbolic images from the psychoanalytic angle, it could be found that these symbols uniformly convey some special senses of unconsciousness or some desires. In The Hamlet, there are three main symbols which symbolize unconscious desires.

\subsection{The Eula's Buggies}

The first symbol is the buggies Eula uses. Eula is a complicated figure in the novel. As the heroine, she is seen as a combination of devil, human and saint. In light of her intricate nature, the buggies she rides definitely mean a lot. It symbolizes the original and unconscious sexual desire of the male people of the Frenchman's Bend. According to Freudian theory, symbols are agents that combine the consciousness and the unconsciousness together. Faulkner's using Eula's buggy as a symbol of unconscious desires in the heart of male villagers unites the superficial meaning and deep meaning of words of the novel, thus, the usage vivifies the plot of the novel, deepens the theme of The Hamlet, enriches the image of Eula and reveals the basic human nature and unconscious desires.

Buggies appear throughout the whole Chapter Two. When the buggy Eula uses first appears, it is furnished by red wheels, fringed parasol ceiling and new brass-studded harnesses. The fatty white horse and the tall brown horse draggle the buggy running around the roads in the village, summoning the original desire. Every time when Eula is driven by in the buggy, all men in the village would go crazy about her or even fight for her. For example, when the buggy of McCarron is often seen around Eula Varner's house, men in the village go mad and sent McCarron a warning. There is a proof that could be cited here from Chapter Two of Book Two:

... So they sent McCarron a formal warning in writing with their names signed. One of them rode the twelve miles to his mother's house one night and fastened the notice to the door. (William Faulkner, 1991, P. 152-153)

From above narration, it can be seen easily that men in the village are very furious for the appearing of McCarron's buggy in Eula's daily life. What's more, a formal warning is just a beginning of their crazy behavior. When their warning does not arouse McCarron's enough attention, they even think of an attack on McCarron.

Yet for almost another week he foiled them. They were trying to take him when he was in the buggy alone, either before he had reached the Varner house or after he had left it. But the mare was too fast for them to overtake... (William Faulkner, 1991, P. 152-153)

Actually, they did put their idea into practice at last. "So they forced at last to ambush him at the ford with Eula in the buggy when the mare stopped to drink." (William Faulkner, 1991, P. 153)

The buggies are the buggies of Eula's youth. They represent Eula's great charms. The anger that men in the village feel and the crazy behavior they do when they see McCarron's buggy constantly appear near the house of Eula well explain this point. The buggy is a simple transporting tool at that time, but it acquires an important symbolic significance of 
unconscious sexual desire of men in the Old Frenchman's bend in the novel by Faulkner's careful design.

\subsection{The Village's Activities}

The second outstanding symbol in the novel is all kinds of activities organized in the village, such as singings and baptizing. These activities, as a basic part of people's daily life, are often considered as common social events, but in the novel of The Hamlet, they also symbolize unconscious sexual desire of men in the Old Frenchman's Bend. It is on such occasions that men could see their goddess Eula, and that people's desire could be released, so these activities are given symbolic meaning of sexual desire in the novel. In Chapter Two of Book Two, there is an insightful description of singings and baptizing, which well illustrates the point. It is as follows:

They would meet again at the singings and baptitsings and picnics about the country. It was the election year ..., and the young people in groups or pairs moved about the grove or, in whatever of seclusion the girls could be enticed into, engaged in the clumsy horseplay of adolescent courtship or seduction. She listened to no speeches and set no tables and did no singing. Instead, with those two or three or four lesser girls she sat, nucleus of that loud frustrated group; ... while refusing herself to be pawed at.... ruthless chastity impervious even to the light precarious balance, the actual overlapping, of Protestant religious and sexual excitement. (William Faulkner, 1991, P. 142-143)

In the above description, we can find many expressions loaded with sexual implication, such as "seclusion the girls", "adolescent courtship", "ruthless chastity", "sexual excitement" and so on. All these expressions obviously demonstrate the real objective and significance of these social activities, that is, they are for releasing passion and for seducing girls, especially for Eula. In the next paragraph of the same page in the novel, there is a further explanation: “..., though if she were aware that they invited her so that the boys would come, nobody ever divined this from her behavior either." (William Faulkner, 1991, P. 143) This shows that Eula is the original motivation of men in the village to come to these activities, fully stating the unconscious desires of male villagers.

On the surface, singings, baptizing and picnics are common social occasions in the Western society, so it is quite reasonable for Faulkner to describe these occasions in the novel. However, Faulkner does not mean to describe these occasions only for the plot's sake, and his real aim is on the symbolic meaning of these descriptions. Eula is the dreamy girl of men in the village, so in order to see her, they think out all kinds of reasons to organize such activities as singing party, baptizing ceremony or picnics. These activities symbolize unconscious sexual desire of men in the Frenchman's Bend.

\subsection{People's Purchase}

The third apparent symbol repeated in the novel is the villagers' purchasing behavior. Superficially, purchasing is for a living, however, when it is given a careful examination, villagers' purchasing exposes their hidden desires. In The Hamlet, the stores in the village are rather important places, where all kinds of goods or products are sold and bought here. The reason for their importance is that villagers' needs could be satisfied through purchasing products in these stores. The products are often laden with symbolic value, and the purchasing needs actually cast light upon people's desires. In this sense, villagers' purchase could be understood symbolically as the satisfaction of their desires.

In the novel, Faulkner mentioned various purchasing behavior, for example, Jody's buying suits, villagers' buying horses, and the little boy's buying biscuits and so on. Among them, the most notable buying event is the purchase of dappled horses narrated in Book Four. Horses, as means of production and transportation, play a very important role in villagers' life in the Southern America of early $20^{\text {th }}$ century, thus horses are vital products with special significance in the novel.

The dappled horse event happened in the Chapter One of Book Four is actually a well-designed business trap by Flem Snopes, however, the villagers buy the horses at all costs without realizing it. Take the newcomer Henry as an example. In terms of his family's economic state, he cannot afford to buy a horse, because his wife objected: "we got chaps in the house that never had shoes last winter. We aint got corn to feed the stock. ..." (William Faulkner, 1991, P. 322), but he gets one regardless of his wife's strong opposition. The reason for the purchasing horses by all means is that the horse can bring people great benefit and hope for making more money. Some hints could be found from the Texan seller's words:

"Them ponies is gentle as a dove, boys. The man that buys them will get the best piece of horseflesh he ever forked or druv for the money...."... the Texan said: "You're just in time to buy a good gentle horse cheap." (William Faulkner, 1991, P. 315)

From the above promotional words of the Texan, it is seen obviously that the Texan fully understands villagers' need and desire for money, which is the crucial factor for a successful selling and is also the reason why people are persuaded into buying the horses without recognizing the pitfall. It is proved that people's purchasing behavior is motivated and 
driven by their unconscious desires. In other words, behind the purchasing behavior of the villagers are their desires for wealth and social status. Therefore, in terms of Freudian psychoanalysis, people's purchase symbolizes their unconscious social desire.

\section{Conclusion}

William Faulkner is one of the greatest writers of $20^{\text {th }}$ century in America. During his whole life, he created more than one hundred long novels and short stories which set in the Southern part of America. His writing features are rather prominent, for example, most of his works are influenced by biblical culture; the stream of consciousness is used frequently; and the use of symbols is quite outstanding. The Hamlet, a representative novel of Faulkner's later career, is a good case of using symbols to develop the plot and mold the characters, and symbols in The Hamlet can be made a Freudian psychoanalysis.

Freud, the founder of psychoanalysis, conceived and worked out a set of theories concerning unconsciousness, personality structure and symbolism. As for symbolism, he put forward that any literary and artistic works are symbolic day-dreams which reveals unconscious desires. In Faulkner's The Hamlet, there are three main symbols that symbolize unconscious desires of people. The first one is the buggies Eula uses, symbolizing the original sexual desire of the male villagers in the Frenchman place. The second one is the activities such as singings and baptizing, which involves people's releasing their unconscious desire for sex. The third one is the people's purchasing, which is an abstract symbol demonstrating people's unconscious pursuit for wealth and social state.

Faulkner's symbolic images are not obtained by accident, but designed to strengthen the theme and help to create characters. Faulkner reveals human nature of people in the novel on the deeper level through using symbols like Eula's buggies, the village's activities and people's purchasing behavior. Faulkner's use of these symbols demonstrates people's psychology and nature more deeply and more systematically. The usage deepens the theme of the novel and benefits the characterization of the novel, making The Hamlet a novel more meaningful in theme and more artful in writing technique and more readable in value.

\section{References}

Blotner, J., \& Polk, N. (1990). Faulkner Novels 1936-1940. New York: The Library of America.

Elmore, O. (2007). Apophasis, Aletheia: William Faulkner's The Hamlet”. New South Wales: Nebula.

Frankland, G. (2000). Freud's Literary Culture. Cambridge: Cambridge University Press. http://dx.doi.org/10.1017/CBO9780511485763

Freud, S. (1923). Introductory Lectures on Psycho-analysis. London: International Psycho-analytical Press.

Greet, T. Y. (1957). The Theme and Structure of Faulkner's The Hamlet. New York: PMLA.

Guerard, A. J. (1976). The Triumph of the Novel: Dickens, Dostoevsky, Faulkner. Oxford: Oxford University Press.

Han, Q. Q., \& Yang, J. C. (2010). Products, Clothes, and Advertisements, A Cultural Analysis of Faulkner's The Hamlet, Journal of PLA University of Foreign Language.

Holmes, C. D. (1996). Annotations to William Faulkner's The Hamlet. New York \& London: Garland Publishing, Inc..

Liao L. L. (2008). A Freudian Psychoanalytic Interpretation of Rabbit, Run. Guilin: Guangxi Normal University.

William, F. (1991). The Hamlet. New York: Vintage International of Random House, Inc.

Xiao, M. H. (1997). Studies of William Faulkner. Beijing: Foreign Language Teaching and Research Press.

Yao, N. Q. (2004). About Studies of William Faulkner. Tianjin: Free Forum of Literature.

Zhou, Y. (2015). On the Application of Symbolism in Faulkner's works. Beijing: Language Planning.

Zhu, G. (2006). A History of the 20th Century Literary Theory in the West. Beijing: Peking University Press.

\section{(cc) EY}

This work is licensed under a Creative Commons Attribution 3.0 License. 